Jurnal Akuntansi dan Manajemen

Vol.15, No.1, 2020, Hal. 91-101

\title{
Analisis Sistem Pengadaan Kendaraan Dinas Operasional Pemerintah Melalui Sistem Pembelian dan Sewa (Studi Pada Politeknik Negeri Padang)
}

\author{
Elfitri Santi ${ }^{1)}$, Afridian Wirahadi' ${ }^{2)}$, Arif Wahyu Saputra ${ }^{3)}$, \\ Rasyidah Mustika ${ }^{4}$, Ferdawati $^{5}$ ) \\ ${ }^{1}$ Jurusan Akuntansi, Politeknik Negeri Padang \\ email: elfitrisanti.pnp@gmail.com \\ ${ }^{2} J u r u s a n$ Akuntansi, Politeknik Negeri Padang, \\ email: afridianpadang@gmail.com \\ 3Jurusan Akuntansi, Politeknik Negeri Padang, \\ email: ariefwahyusaputra8@gmail.com \\ 4Jurusan Akuntansi, Politeknik Negeri Padang, \\ email: titik.mustika@gmail.com \\ 5Jurusan Akuntansi, Politeknik Negeri Padang, \\ email:f3rd4@yahoo.com
}

\begin{abstract}
The official goverment vehicles supply demand the goverment allocate fund in carefully and precise based on the needs. The value of money analysis between buy, rent, and leasing to supplying the official vehicles in Polytechnic State's of Padang. intent on calculating, analyze, and comparing which alternative that make more value of money between the provisions system of buying, renting and leasing. Methods this Research is Qualitative and The analysis instrument that use in this research is Net Present Value Method also calculating the cost benefit analysis. The research examine 3 type or merk that represent the officeholder vehicles, such as Toyota Hiace Commuter, Kijang Innova V A/T, dan Avanza Veloz. The result of this research indicated that officeholder vehicles supplying system through the buying system is has more benefit that follow by the leasing system and the renting system. This research result could be a reference for Goverment in choosing supplying system of officeholder vehicles in Padang State's Polytechnic.
\end{abstract}

Keywords : governmental accounting, officeholder vehicles, net present value, buying, leasing, renting

\begin{abstract}
Abstrak
Pengadaan kendaraan operasional dinas menuntut pemerintah dapat mengalokasikan dana secara cermat dan tepat sesuai dengan kebutuhan. Analisa value for money secara membeli, menyewa dan leasing dalam kegiatan pengadaan kendaraan dinas pada Politeknik Negeri Padang bertujuan untuk menghitung, menganalisa serta membandingkan alternatif manakah yang lebih value for money diantara sistem pengadaan membeli, menyewa dan leasing. Jenis Penelitan yang digunakan adalah penelitian kualitatif serta analisis yang digunakan dalam penelitian ini, yaitu, Metode Net Present Value (NPV) dengan juga memperhitungkan nilai biaya manfaat. Penelitian meneliti tiga merek/tipe kendaraan yang mewakili kendaraan dinas antara lain; Toyota Hiace Commuter, Kijang Innova V A/T, dan Avanza Veloz. Hasil penelitian diketahui bahwa sistem pengadaan kendaraan dinas melalui pembelian secara tunai untuk ketiga tipe kendaraan lebih menguntungkan, diikuti dengan sistem leasing dan sewa secara berurutan. Hasil penelitian ini dapat sebagai rujukan kepada pemerintah dalam memilih sistem pengadaan dinas di lingkungan pemerintah masing-masing.
\end{abstract}

Kata kunci: Akuntansi Pemerintahan, Kendaraan Dinas, Net Present Value, Membeli, Leasing, Sewa 
PENDAHULUAN

\section{Latar Belakang}

Penerapan good governace dan standar akuntansi pemerintahan dengan komitmen organisasi yang tinggi mempunyai pengaruh terhadap akuntabilitas keuangan. Pemahaman dan penggunaan Standar Akuntansi Pemerintahan mutlak dilakukan agar laporan keuangan berkualitas dan dapat digunakan untuk menilai kinerja aparatur pemerintah yang bersih dan berwibawa (Elvira, 2011).

Undang-undang Nomor 17 Tahun 2013 tentang Keuangan Negara pada Pasal 3 ayat 1 menjelaskan bahwa keuangan negara dikelola secara tertib, taat pada peraturan perundang-undangan, efesien, ekonomis, efektif, transparan, dan bertanggungjawab dengan memperhatikan rasa keadilan dan kepatutan. Hal ini yang menjadi alasan utama bagi pengambil kebijakan untuk berhati-hati dalam mengelola keuangan instansinya.

Penyediaan sarana dan prasarana pemerintah dapat dilakukan melalui pengadaan barang dan jasa. Merujuk pada Peraturan Presiden Republik Indonesia Nomor 4 Tahun 2015 tentang Pengadaan Barang/Jasa Pemerintah yang terakhir diubah dengan Peraturan Presiden Nomor 16 Tahun 2018 tentang Perubahan atas Peraturan Presiden Nomor 15 Tahun 2015 tentang Pengadaan Barang/Jasa Pemerintah pada Bab 1 Pasal 1 menjelaskan bahwa pengadaan barang dan jasa merupakan kegiatan untuk memperoleh barang dan jasa oleh kementrian atau lembaga atau satuan kerja perangkat daerah atau instansi yang prosesnya dimulai dari perencanaan kebutuhan sampai diselesaikannya seluruh kegiatan untuk memperoleh barang/jasa. Pelaksanaan pengadaan barang/jasa dilakukan dengan dua cara. Kedua cara tersebut yaitu swakelola dan penyedia barang/jasa.

Kendaraan dinas pada instansi pemerintahan sangat diperlukan kebaradaannya dalam menunjang kegiatan operasional pemerintahan. Pengadaan kendaraan dinas sangat diperlukan untuk memenuhi kebutuhan akan kendaraan dinas dalam pelaksanaan tugas pokok instansi di lingkungan pemerintahan. Pengadaan kendaraan dinas ini merupakan pengadaan aset tetap pemerintah yang menggunakan anggaran pendapatan dan belanja negara (APBN) atau anggaran pendapatan dan belanja daerah (APBD). Dana APBN atau APBD tersebut salah satu sumbernya berasal dari pajak yang dibayarkan oleh masyarakat.

Masalah yang sering dihadapi dan dialami oleh pemerintah dalam proses pengadaan kendaraan dinas yaitu adanya potensi penyelewengan yang dilakukan oleh aparat pemerintah ataupun penyedia barang/jasa sehingga dapat menimbulkan kerugian keuangan negara. Potensi penyelewengan terhadap kendaraan pemerintah dapat diminimalisirkan dengan pemilihan alternatif dalam pengadaan kendaraan dinas, yaitu dengan cara membeli, menyewa dan leasing kendaraan dinas tersebut. Pengadaan dengan sistem beli pada prinsipnya adalah melakukan pemindahan kepemilikan (shifting the ownership) suatu aset kendaraan dari pihak penjual kepada pembeli. Risiko kepemilikan aset juga berpindah dari pihak penjual kepada pihak pembeli segera setelah aset tersebut diserah terima oleh para pihak. Pihak pembeli selanjutnya akan menanggung biaya pembelian, biaya operasional, biaya pemeliharaan, dan biaya penyusutan aset kendaraan.

Pengadaan kendaraan dengan sistem sewa berarti pihak pemerintah menggunakan kendaraan dinas yang disediakan oleh pihak penyewa. Pihak pemerintah akan membayar nilai sewa dari setiap kendaraan kepada pihak penyewa. 
Pihak penyewa akan menanggung seluruh biaya pembelian, pemeliharaan, pajak, dan penyusutan aset kendaraan. Kontrak kerja sama antara pemerintah dan penyewa mengikat kedua belah pihak dalam penggunaan kendaraan baik hak maupun kewajiban maupun pembagian risiko.

Sistem pengadaan yang lainnya adalah leasing atau dapat disebut juga pembelian secara kredit. Pihak pemerintah menggunakan kendaraan yang disediakan oleh pihak lessor dengan perjanjian antara kedua pihak yang telah disepakati. Pihak pemerintah sebagai lessee bersedia membayar pembiayaan kendaraan secara angsuran, biaya pemeliharaan, pajak dan nilai sisa dari kendaraan, diakhir waktu yang telah disepakati kendaraan dimiliki oleh lessee.

Beberapa alasan yang menjadi dasar dalam pengambilan kebijakan untuk melakukan sistem sewa kendaraan dinas oleh intansi pemerintah adalah sebagai berikut:

1. Pemerintah daerah tidak perlu lagi mengurus hal-hal teknis terkait dengan servis kendaraan, penggantian suku cadang, perbaikan akibat kecelakaan dan perpanjangan STNK karena hal ini menjadi tanggungjawab dari pihak penyewa kendaraan, sehingga aparatur dapat fokus kepada pekerjaannya.

2. Mengurangi beban APBD karena pemerintah tidak lagi menganggarkan dana untuk biaya perawatan kendaran, penggantian suku cadang, perbaikan akibat kecelakaan dan perpanjangan STNK. Pemerintah daerah hanya cukup menganggarkan sebesar nilai sewa pada kontrak yang telah disepakati.

3. Dapat menghemat anggaran belanja pemerintah daerah dalam pengadaan kendaraan. Pemerintah daerah tidak perlu menganggarkan dana yang sangat besar untuk membeli kendaran.

4. Mengurangi kecurangan dalam pengadaan. Dengan sistem sewa dapat mengurangi penggelembungan (mark up) dana dan biaya yang dikeluarkan dalam pengadaan kendaran. Dalam sistem sewa semua dana yang dikeluarkan sudah tercakup dalam satu penawaran atau paket harga.

5. Meningkatkan efektivitas kerja pegawai. Sewa menjadikan pegawai yang ada dapat lebih berkonsentrasi dalam tugas pokok dan fungsinya, tidak lagi terbebani dengan detail-detail yang terkait dengan pengelolaan aset internal satuan kerjanya. Hal ini akan menjadikan pekerjaan dapat terlaksana dengan lebih cepat dan akhirnya pegawai-pegawai pemerintah dapat lebih tanggap terhadap realisasi harapan masyarakat.

Penelitian ini akan memperoleh hasil dan rekomendasi yang tepat terkait dengan kebijakan apakah membeli atau menyewa kendaraan dinas. Selain itu, penelitian ini diharapkan dapat memberikan saran dan masukan kepada pemerintahan untuk melakukan tindakan paling efesien dalam hal pengadaan kendaraan dinas.

\section{Rumusan Masalah}

Kendaraan dinas merupakan salah satu aset tetap pemerintah yang digunakan untuk mobilisasi kegiatan operasional. Pengadaan kendaraan dinas pada pemerintah daerah dilakukan untuk dapat memenuhi kebutuhan akan sarana transportasi yang dapat menunjang tugas pokok dan fungsi pemerintahan. Sebagaimana informasi awal yang diketahui bahwa pengadaan kendaraan dinas seluruh SKPD membutuhkan anggaran yang besar, sedangkan anggaran nasional terbatas. Untuk itu diperlukan 
suatu sistem baru dalam pengadaan kendaraan dinas tersebut. Sistem baru itu yakni sistem sewa.

Pada pelaksaaan pengadaan kendaraan dinas melalui sistem pembelian, pihak penyedia barang yang menjadi pemenang dalam tender pengadaan biasanya merupakan pihak yang memiliki hubungan kekerabatan dengan pejabat atau panitia pelaksana pengadaan sehingga memunculkan tindak pidana korupsi dalam pengadaan tersebut (Datau, 2016). Selain itu, pemerintah juga diwajibkan menyediakan anggaran pemeliharaan dan perbaikan kendaraan dinas yang telah menjadi aset tetap pemerintahan. Rumusan masalah yang akan dijawab pada penelitian ini adalah Bagaimanakah sistem pengadaan kendaraan dinas yang sebaiknya dilakukan oleh Politeknik Negeri Padang?

\section{METODE PENELITIAN}

\section{Jenis Penelitian}

Penelitian ini bersifat policy-oriented research yang bertujuan untuk memeriksa dan mengevaluasi kebijakan pemerintah di Lembaga Pemerintahan Perguruan Tinggi dalam hal pegelolaan anggaran. Penelitian ini menggunakan metode kualitatif dengan pendekatan analisis deskriptif. Pendekatan penelitian ini dilakukan dengan menganalisis kemudian membandingkan pengadaan barang/jasa pemerintah di Perguruan Tinggi Vokasi Politeknik Negeri Padang dengan prinsip-prinsip pengadaan barang/jasa sebagaimana tercantum dalam Peraturan Presiden Nomor 16 Tahun 2018 tentang Pengadaan Baran/Jasa Pemerintah

a. Observasi, yaitu pengamatan secara langsung terhdapa objek proses kegiatan perusahaan untuk mendapatkan gambaran sebenarnya

b. Wawancara, yaitu pengumpulan data yang dilakukan dengan cara mengajukan pertanyaan-pertanyaan secara lisan kepada pihak-pihak yang berkepentingan.

c. Dokumen Review, penelitian ini dilakukan untuk memperoleh referensi untuk menyelesaikan masalah yang akan diteliti. Dalam penelitian ini penulis membaca dan mempelajari buku dan materi yang berhubungan dengan masalah yang diteliti.

\section{Metode Analisis Data}

Analisis data yang digunakan dalam penelitian ini dilakukan secara kuantitatif yaitu menganalisis kelayakan finansial pada saat melakukan pengadaan kendaraan dinas melalui beli, leasing dan sewa. Dalam analisis kuantitatif dilakukan perhitungan nilai uang (value for money) dengan membandingkan biaya dan manfaat yang diperoleh pada masa sekarang dengan masa yang akan dating melalui tingkat diskonto tertentu. Data diolah dan diinterprestasikan secara deskriptif. Analisis kelayakan menggunakan perhitungan kriteria-kriteria investasi yaitu net present value (NPV).

\section{HASIL DAN PEMBAHASAN}

\section{Sejarah Politeknik Negeri Padang}

Politeknik Negeri Padang didirikan pada tahun 1987, dimana keberadaan Politeknik merupakan salah satu dari 17 (tujuh belas) Politeknik pertama di Indonesia. Yang bertujuan menjawab tantangan perkembangan dunia industri dan dunia usaha yang 
menuntut kompetensi dari tenaga-tenaga kerja terampil, profesional dan mandiri yang lebih mengutamakan attitude, knowledge, dan skill serta kompeten dibidangnya.

Pada awal berdirinya dikenal dengan nama Politeknik Engineering Universitas Andalas, yang hanya menyelenggarakan Program Studi Bidang Rekayasa atau Keteknikan. Dengan Program Studi Teknik Mesin, Sipil, Listrik, dan Elektronika Komunikasi. Pada tahun 1997 diganti menjadi Politeknik Universitas Andalas, dengan pertimbangan karena dibuka Program Studi Bidang Tataniaga (Akuntansi dan Administrasi Bisnis). Dalam rangka memenuhi tuntutan dunia kerja maka Politeknik membuka program studi baru, sampai saat ini Politeknik telah mempunyai 20 Program Studi (12 Program Studi DIII dan 8 Program Studi DIV).

Dalam rangka menuju kemandiriannya maka politeknik saat itu mempunyai dua nama yaitu Politeknik Universitas Andalas dan Politeknik Negeri Padang. Politeknik. Politeknik Negeri Padang hadir tengah-tengah masyarakat dengan menerapkan sistem pendidikan yang konsisten pada jalur vokasional dengan menerapkan sistem pembelajaran yang aplikatif serta secara terus menerus menyesuaikan diri dengan perkembangan dunia industri dan dunia usaha yang ada untuk menghasilkan tenaga kerja yang berkompeten sesuai dengan permintaan pasar dan mampu bersaing pada era persaingan global.

Sebagai lembaga pendidikan yang mengutamakan mutu dan kepercayaan dunia industri dan dunia usaha Politeknik Negeri Padang menerapkan sistem paket semester dengan sistem pembelajaran $60 \%$ praktek dan $40 \%$ teori. Penerapan sistem praktek bengkel yang menyamai sistem di industri dan dunia usaha merupakan suatu langkah konsistensi untuk menyiapkan Tenaga Ahli Madya (Amd) dan Sarjana Sain Terapan (STR) yang terampil dan mempunyai etos kerja sesuai kebutuhan industri. Rancangan kurikulum pendidikan yang bersifat dinasmis yang dirancang sesuai dengan kebutuhan industri atau pasar dan tetap mengacu kepada peraturan pemerintah serta undang-undang pendidikan yang berlaku, merupakan suatu langkah strategis yang diterapkan di Politeknik Negeri Padang dalam menghasilkan lulusan yang sangat diminati oleh dunia usaha dan dunia industri terkemuka dan dimancanegara.

\section{Jumlah Kendaraan Dinas Politeknik Negeri Padang}

Berdasarkan hasil data kendaraan dan observasi yang penulis lakukan, jumlah kendaraan dinas operasional di lingkungan Politeknik Negeri Padang yang tersedia adalah 22 unit. Jenis dan umur kendaraan dinas dapat disajikan pada tabel 1. sebagai berikut;

Tabel 1. Jenis dan Jumlah Kendaraan Dinas 


\begin{tabular}{|r|r|r|r|r|r|}
\hline \multicolumn{1}{|c|}{ Tahun } & \multicolumn{1}{|c|}{ Umur } & \multicolumn{1}{l|}{ Deluxe } & \multicolumn{1}{l|}{ Standar } & \multicolumn{1}{l|}{ Operasional } & \multicolumn{1}{l|}{ Jumlah } \\
\hline 2003 & 16 & 1 & 0 & 0 & 1 \\
\hline 2004 & 15 & 0 & 1 & 0 & 1 \\
\hline 2005 & 14 & 0 & 0 & 1 & 1 \\
\hline 2006 & 13 & 1 & 0 & 3 & 4 \\
\hline 2007 & 12 & 0 & 0 & 2 & 2 \\
\hline 2009 & 10 & 1 & 0 & 2 & 3 \\
\hline 2011 & 8 & 3 & 0 & 0 & 3 \\
\hline 2012 & 7 & 1 & 0 & 0 & 1 \\
\hline 2014 & 5 & 1 & 0 & 2 & 3 \\
\hline 2015 & 4 & 0 & 1 & 0 & 1 \\
\hline 2017 & 2 & 1 & 0 & 0 & 1 \\
\hline 2018 & 1 & 1 & 0 & 0 & 1 \\
\hline \multicolumn{2}{|c|}{ Total } & 10 & 2 & 10 & 22 \\
\hline
\end{tabular}

Sumber : data diolah 2019

Berdasarkan tabel diatas dapat dilihat bahwa jumlah keseluruhan kendaraan dinas adalah 22 unit yang terbagi atas ketiga golongan yaitu (1) deluxe yang memiliki kapasitas cc kendaraan diatas 2000, (2) standar yang memiliki kapasitas cc diantara 1800 - 2000, dan (3) operasional yang memiliki kapasitas cc dibawah 1800.

Berdasarkan Keputusan Mentri Keuangan No. 59/KMK.06/2013 tentang Tabel Masa Manfaat Dalam Rangka Penyusutan Barang Milik Negara Berupa Aset Tetap Pada Entitas Pemerintah menyatakan bahwa masa manfaat kendaraan dinas darat selama 7 tahun. Jika dilihat dari tabel diatas, kendaraan yang berumur 7 tahun terhitung dari tahun 2012, berjumlah 7 unit yang terdiri dari kendaraan operasional deluxe sebanyak 4 unit, kendaraan standar sebanyak 1 unit, dan kendaraan operasional sebanyak 2 unit.

\section{Biaya Operasi Dan Pemeliharaan Kendaraan Dinas}

Biaya perawatan dan pemeliharaan kendaraan dinas di Politeknik Negeri Padang dapat dibedakan menjadi 2 kategori, yaitu biaya perawatan service dan belanja pelumas kendaraan dinas. Perawatan dan pemeliharaan kendaraan dinas dilakukan secara rutin dan berkala agar kendaraan dinas dapat digunakan dalam kondisi baik dan aman.

Tabel 2. Standar Pemeliharaan dan Pergantian Suku Cadang Kendaraan 


\begin{tabular}{|c|l|c|c|}
\hline \multirow{2}{*}{ No } & \multirow{2}{*}{ Uraian } & \multicolumn{2}{c|}{ Pemakaian Pertahun } \\
\cline { 3 - 4 } & & Jumlah & Satuan \\
\hline 1 & Oli Mesin SAE 20w -50 & 24 & Liter \\
\hline 2 & Oli Persenelling & 6 & Liter \\
\hline 3 & Oli Gardan & 6 & Liter \\
\hline 4 & Saringan Oli & 2 & Unit \\
\hline 5 & Saringan Minyak & 3 & Unit \\
\hline 6 & Saringan Udara & 2 & Unit \\
\hline 7 & Minyak Rem Perkaleng & 4 & Kaleng \\
\hline 8 & Air Accu per botol & 12 & Botol \\
\hline 10 & Service & 4 & Kegiatan \\
\hline 11 & Ban Luar & 2 & Unit \\
\hline 12 & Ban Dalam & 2 & Unit \\
\hline 14 & Kain Rem depan & 2 & Set \\
\hline 15 & Kain Rem Belakang & 2 & Set \\
\hline 16 & Kain Kopling & 1 & Set \\
\hline 17 & Tali Kipas & 1 & Unit \\
\hline 18 & Kolahar Roda & 2 & Set \\
\hline 19 & Busi & 8 & Unit \\
\hline 20 & Platina & 12 & Unit \\
\hline 21 & Cuci Kolong & 1 & Kali \\
\hline 22 & Pengurusan STNK & & Kali \\
\hline & & & \\
\hline
\end{tabular}

Standar pemeliharaan diatas merupakan hasil survei dan wawancara dengan pihak showroom kendaraan. Pemeliharaan dan pergantian suku cadang tidak menutup kemungkinan dilakukan melebihi dari standar pemeliharaan dan pergantian suku cadang, hal ini biasanya terjadi apabila terdapat suatu hal yang tidak terduga atau frekuensi penggunaan kendaraan dinas keluar atau dalam kota juga mempengaruhi pergantian suku cadang tersebut.

\section{Representatif Kendaraan Dinas}

Berikut merupakan tabel representasi kendaraan dinas Politeknik Negeri Padang;

Tabel 3. Representatif Kendaraan Dinas

\begin{tabular}{|c|c|c|c|}
\hline Tipe Kendaraan & Kendaraan Representasi & Cylinder Capacity & Jenis Bahan Bakar \\
\hline Delucxe & Toyota Hiace Commuter & $2494 \mathrm{CC}$ & Premium \\
\hline Standar & Kijang Innova V A/T & $1998 \mathrm{CC}$ & Premium \\
\hline Operasional & Toyota Avanza 1,5 Veloz A/T & $1495 \mathrm{CC}$ & Premium \\
\hline
\end{tabular}




\section{Berikut merupakan struktur biaya kendaraan dinas Politeknik Negeri Padang}

Struktur biaya dibawah ini digunakan untuk menghitung kelayakan ekonomis antara system pembelian, system sewa maupun system leasing untuk 3 kelompok kendaraan dinas, yakni kelompok deluxe (Toyota Hiace Commuter), kelompok standar (Kijang Innova V A/T) dan kelompok operasional (Avanza Veloz).

Tabel 4. Struktur biaya kendaraan dinas Politeknik Negeri Padang

\begin{tabular}{|c|c|c|c|c|}
\hline No & $\begin{array}{l}\text { Komponen Biaya } \\
\text { Kendaraan }\end{array}$ & Kriteria & & Nilai \\
\hline 1 & Inflasi/tahun & Inflasi Rata-rata Kota Padang & & $4,86 \%$ \\
\hline \multirow[t]{7}{*}{2} & Harga Kendaraan Baru & Toyota Hiace Cummuter & $R p$ & 479.800 .000 \\
\hline & & Toyota Hilux Pick Up & $R p$ & 421.550 .000 \\
\hline & & Suzuki Grand Vitara 2.4 & $\mathrm{Rp}$ & 365.500 .000 \\
\hline & & Kijang Innova V AT & $\mathrm{Rp}$ & 395.900 .000 \\
\hline & & $\begin{array}{l}\text { Toyota Avanza } 1,5 \text { Veloz } \\
\mathrm{A} / \mathrm{T}\end{array}$ & $\mathrm{Rp}$ & 246.900 .000 \\
\hline & & Toyota Avanza $1,5 \mathrm{G} \mathrm{M} / \mathrm{T}$ & $\mathrm{Rp}$ & 228.600 .000 \\
\hline & & Toyota Avanza $1,3 \mathrm{G} \mathrm{M} / \mathrm{T}$ & $\mathrm{Rp}$ & 227.000 .000 \\
\hline 3 & Asur ansi/tahun & Asuransi Rata-rata & & $2,50 \%$ \\
\hline \multirow[t]{6}{*}{4} & Depresiasi/tahun & Toyota Hiace Cummuter & $\mathrm{Rp}$ & 68.542 .857 \\
\hline & & Toyota Hilux Pick Up & $\mathrm{Rp}$ & 60.221 .429 \\
\hline & & Suzuki Grand Vitara 2.4 & $\mathrm{Rp}$ & 52.214 .286 \\
\hline & & Kijang Innova V AT & $\mathrm{Rp}$ & 56.557 .143 \\
\hline & & $\begin{array}{l}\text { Toyota Avanza } 1,5 \text { Veloz } \\
\mathrm{A} / \mathrm{T}\end{array}$ & $\mathrm{Rp}$ & 35.271 .429 \\
\hline & & Toyota Avanza $1,5 \mathrm{G} \mathrm{M} / \mathrm{T}$ & $\mathrm{Rp}$ & 32.657 .143 \\
\hline
\end{tabular}

\begin{tabular}{|c|c|c|c|c|}
\hline & & Toyota Avanza $1,3 \mathrm{G} \mathrm{M} / \mathrm{T}$ & $\mathrm{Rp}$ & 32.428 .571 \\
\hline \multirow[t]{3}{*}{5} & Bunga Leasing/tahun & Toyota Hiace Cummuter & $\mathrm{Rp}$ & 10.104 .882 \\
\hline & & Kijang Innova V AT & $\mathrm{Rp}$ & 8.379 .689 \\
\hline & & $\begin{array}{l}\text { Toyota Avanza } 1,5 \text { Veloz } \\
\text { A/T }\end{array}$ & $\mathrm{Rp}$ & 5.376 .000 \\
\hline \multirow[t]{6}{*}{6} & Biaya Sewa/tahun & Toyota Hiace Cummuter & $\mathrm{Rp}$ & 180.998 .400 \\
\hline & & $\begin{array}{l}\text { Toyota Hillux PU Single } \\
\text { Cabin } 2.0 \mathrm{M} / \mathrm{T}\end{array}$ & $\mathrm{Rp}$ & 84.100 .800 \\
\hline & & $\begin{array}{l}\text { Toyota Hillux PU Single } \\
\text { Cabin } 2.5 \mathrm{M} / \mathrm{T}\end{array}$ & Rp & 77.632 .800 \\
\hline & & Kijang Innova V AT & $\mathrm{Rp}$ & 116.672 .400 \\
\hline & & $\begin{array}{l}\text { Toyota Avanza } 1,5 \text { Veloz } \\
\mathrm{A} / \mathrm{T}\end{array}$ & $\mathrm{Rp}$ & 80.455 .200 \\
\hline & & Toyota Avanza $1,5 \mathrm{G} \mathrm{M} / \mathrm{T}$ & $\mathrm{Rp}$ & 74.340 .000 \\
\hline
\end{tabular}

\begin{tabular}{|c|l|l|lr|}
\hline 7 & Tingkat Kenaikan Biaya & & \multicolumn{2}{|c|}{$\begin{array}{c}\text { Berdasarkan Nilai } \\
\text { Inflasi }\end{array}$} \\
\hline 8 & Service Besar & Toyota Hiace Cummuter & Rp & 1.262 .000 \\
\hline & & Toyota Hilux Pick Up & Rp & 1.267 .500 \\
\hline & & Suzuki Grand Vitara 2.4 & Rp & 821.300 \\
\hline & & Kijang Innova V AT & Rp & 1.299 .500 \\
\hline & & $\begin{array}{l}\text { Toyota Avanza 1,5 Veloz } \\
\text { AVT }\end{array}$ & Rp & 821.300 \\
\hline & & Toyota Avanza 1,5 G M/T & Rp & 821.300 \\
\hline & & Toyota Avanza 1,3 G M/T & Rp & 821.300 \\
\hline & & & \multicolumn{2}{l}{} \\
\hline 9 & Ganti Ban/Tahun & Toyota Hiace Cummuter & Rp & 910.000 \\
\hline & & Kijang Innova V AT & Rp & 772.000 \\
\hline
\end{tabular}




\begin{tabular}{|c|c|c|c|c|}
\hline & & $\begin{array}{l}\text { Toyota Avanza } 1,5 \text { Veloz } \\
\mathrm{A} / \mathrm{T}\end{array}$ & $\mathrm{Rp}_{\mathrm{p}}$ & 645.000 \\
\hline 10 & Uang Muka Leasing & \multicolumn{3}{|c|}{$30 \%$ dari harga Mobil } \\
\hline 11 & Pajak Kendaraan/Tahun & & \multicolumn{2}{|c|}{$0,50 \%$} \\
\hline & & Toyota Hiace Cummuter & $R p$ & 2.046 .350 \\
\hline & & Toyota Hilux Pick Up & $\mathrm{Rp}$ & 2.107 .750 \\
\hline & & Suzuki Grand Vitara 2.4 & $R p$ & 1.827 .500 \\
\hline & & Kijang Innova V AT & $R_{p}$ & 1.392 .500 \\
\hline & & $\begin{array}{c}\text { Toyota Avanza } 1,5 \text { Veloz } \\
\mathrm{A} / \mathrm{T}\end{array}$ & $\mathrm{Rp}$ & $851.750)$ \\
\hline & & Toyota Avanza $1,5 \mathrm{G} \mathrm{M} / \mathrm{T}$ & $\mathrm{Rp}$ & 1.143 .000 \\
\hline & & Toyota Avanza 1,3 G M/T & $R p$ & 1.135 .000 \\
\hline
\end{tabular}

\section{Perbandingan Net Present Value Pengadaan 1 Unit Kendaraan}

Berikut merupakan perbandingan pengadaan kendaraan dinas Politeknik Negeri Padang:

Tabel 5. Rekapitulasi NPV Untuk I Uniat Kendaraan Dinas Deluxe

\begin{tabular}{|c|c|}
\hline Sistem pengadaan kendaraan & NPV \\
\hline Beli & $(570.763 .913)$ \\
\hline Leasing & $(622.646 .898)$ \\
\hline Sewa & $(1.026 .028 .811)$ \\
\hline
\end{tabular}

Dari table diatas dapat ditarik kesimpulan bahwa untuk kendaraan kelompok deluxe seperti Toyota Hiace Commuter diperoleh hasil system beli adalah pilihan yang paling ekonomis dibanding dengan system pengadaan dengan cara sewa ataupun leasing.

Tabel 6. Rekapitulasi NPV Untuk I Uniat Kendaraan Dinas Standar

\begin{tabular}{|c|c|}
\hline Sistem pengadaan kendaraan & NPV \\
\hline Beli & $(469.969 .026)$ \\
\hline Leasing & $(515.331 .467)$ \\
\hline Sewa & $(661.382 .884)$ \\
\hline
\end{tabular}

Dari table diatas dapat ditarik kesimpulan bahwa untuk kendaraan kelompok standar seperti Kijang Innova V A/T diperoleh hasil sistem beli adalah pilihan yang paling ekonomis dibanding dengan system pengadaan dengan cara sewa ataupun leasing.

Tabel 7. Rekapitulasi NPV Untuk I Uniat Kendaraan Dinas Operasional

\begin{tabular}{|c|c|}
\hline Sistem pengadaan kendaraan & NPV \\
\hline Beli & $(295.988 .133)$ \\
\hline Leasing & $(369.049 .099)$ \\
\hline Sewa & $(456.077 .806)$ \\
\hline
\end{tabular}


Dari table diatas dapat ditarik kesimpulan bahwa untuk kendaraan kelompok operasional seperti Toyota Avanza Veloz diperoleh hasil sistem beli adalah pilihan yang paling ekonomis dibanding dengan system pengadaan dengan cara sewa ataupun leasing.

Perbandingan NPV Pengadaan 1 Unit Kendaraan

Tabel 8. Perbandingan NPV Pengadaan 1 Unit Kendaraan

\begin{tabular}{|l|c|c|c|}
\hline Sistem Pengadaan & Deluxe & Standar & Operasional \\
\hline Beli & $(570.763 .913)$ & $(469.969 .026)$ & $(295.988 .133)$ \\
\hline Leasing & $(622.646 .898)$ & $(515.331 .467)$ & $(369.049 .099)$ \\
\hline Sewa & $(1.026 .028 .811)$ & $(661.382 .884)$ & $(456.077 .806)$ \\
\hline
\end{tabular}

Berdasarkan tabel diatas dapat dilihat bahwa pengadaan kendaraan dinas dengan sistem pengadaan beli tunai lebih ekonomis dibandingkan dengan kedua sistem pengadaan lainnya.

\section{KESIMPULAN}

Dalam penelitian ini dapat diambil kesimpulan bahwa sistem pengadaan kendaraan dinas operasional dalam penelitian ini terdapat tiga sistem, diantaranya sistem pembelian, sistem sewa dan sistem leasing. Setelah itu, didalam penelitian ini membagi kendaraan dinas menjadi 3 kelompok kendaraan yaitu kelompok kendaraan deluxe yakni kendaraan dengan mesin cylinder capacity (cc) diatas 2000 $c c$ dan harga lebih dari 400 juta rupiah. Misalnya Toyota Hiace Commuter, Microbus, Bus AC dan lain sebagainya. Kelompok kendaraan jenis standar yakni kendaraan dengan mesin cylinder capacity (cc) antara 1800-2000 cc dengan harga diatas 300 juta rupiah, misalnya Kijang Innova $\mathrm{V}$ A/T. Kelompok kendaraan ketiga yaitu kendaraan operasional yakni kendaraan dengan mesin cylinde capacity (cc) dibawah 1800 cc dan harga kendaraan dibawah 300 juta rupiah misanya Avanza Veloz, dan Avanza 1,3 G M/T.

Pengadaan untuk kendaraan deluxe dari hasil perhitungan net present value (npv) yakni untuk sistem beli diperoleh hasil minus 570.763.913. Sementara sistem sewa diperoleh hasil minus 1.026.028.811. dan hasil sistem pengadaan leasing diperoleh hasil minus 622.646.898. sehingga sistem pengadaan yang paling baik dilakukan oleh politeknik negeri padang adalah sistem pengadaan beli. Untuk jenis kendaraan standar diperoleh hasil perhitungan npv yakni untuk sistem beli diperoleh hasil minus 469.969.026. Sementara sistem sewa diperoleh hasil minus 661.382.884. dan hasil sistem pengadaan leasing diperoleh hasil minus 515.331.467. sehingga sistem pengadaan yang paling baik dilakukan oleh Politeknik Negeri Padang adalah sistem pengadaan beli. Untuk jenis kendaraan operasional diperoleh hasil perhitungan npv yakni untuk sistem beli diperoleh hasil minus 295.988.133. Sementara sistem sewa diperoleh hasil minus 456.077.806. dan hasil sistem pengadaan leasing diperoleh hasil minus 369.049.099. sehingga sistem pengadaan yang paling baik dilakukan oleh Politeknik Negeri Padang adalah sistem pengadaan beli.. 


\section{DAFTAR REFERENSI}

Ahmad, Afridian Wirahadi. 2013. "Kajian Sistem Pengadaan

Kendaraan Dinas Operasional Pemerintah Kota Padang". Padang.

Daniati, L. \& Farida, L. (2013). "Analisis Pengelolaan Kendaraan Dinas Operasional. Jurna Administrasi Pembangunan", 1(3), 292-295.

Datau, Irham. 2016. "Analisis Pengadaan Kendaraan Dinas Operasional Pemerintah Daerah Melalui Sistem Pembeliandan Sewa (Studi Pada Pemerintah Daerah Kabupaten Boalemo)". Tesis Magister Akuntansi Universitas Gadjah Mada. Yogyakarta.

Elvira, Z. 2011. "Pengaruh Good Governance dan Standar Akuntansi Pemerintahan Terhadap Akuntabilitas Keuangan Dengan Komitmen Organisasi Sebagai Variabel Pemoderasi”. Universitas Pasundan Bandung. Jawa Barat.

Faisal, Nur Ilmi. Dkk. 2017."Analisis Sistem Pengadaan Barang dan Jasa Pada Dinas Pekerjaan Umum dan Penataan Ruang Kota Manado". Fakultas Ekonomi dan Bisnis. Universitas Sam Ratulangi. Manado.

Hansen, Don R dan Maryanne M. Mowen. 2009. "Akuntansi Manajerial. Buku satu. Edisi kedepalan”. Jakarta: Erlangga.

Hansen, Don R dan Maryanne M. Mowen. 2009.

“Akuntansi Manajerial. Buku kedua. Edisi kedepalan". Jakarta: Erlangga.

LKPP. 2010. "Modul Pelatihan Pengadaan Barang/Jasa Pemerintah". Lembaga Kebijakan Pengadaan Barang/Jasa Pemerintah. Jakarta.

LKPP. 2011. "Senarai Pengadaan Barang/Jasa Pemerintah". Jurnal Pengadaan. Lembaga Kebijakan Pengadaan Barang/Jasa Pemerintah. Jakarta.

Republik Indonesia. 2013.Keputusan Mentri Keuangan No. 59/KMK.06/2013 tentang Tabel Masa Manfaat Dalam Rangka Penyusutan Barang Milik Negara Berupa Aset Tetap Pada Entitas Pemerintah.

Republik Indonesia. 2013. Undang-Undang Republik Indonesia Nomor 17 Tahun 2013 Tentang Keuangan Negara.

Republik Indonesia. 2015. Peraturan Presiden Indonesia Nomor 4 Tahun 2015 Tentang Pengadaan Barang/Jasa.

Republik Indonesia. 2018. Peraturan Presiden Indonesia Nomor 16 Tahun 2018 Tentang Pengadaan Barang/Jasa.

www.pnp.ac.id/?page_id=882 diakses pada 20 Juli 2019 